\title{
Conceptual Decontamination and Decommissioning Plan for the Waste Isolation Pilot Plant
}

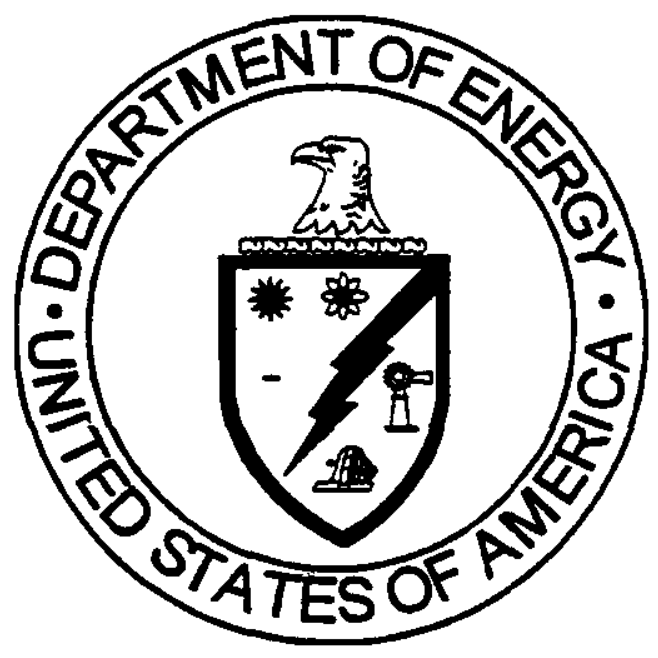

\section{January 1995}

\section{Prepared for \\ United States Department of Energy}

Westinghouse Electric Corporation Waste Isolation Division 


\section{NOTICE}

The Conceptual Decontamination and Decommissioning Plan (D\&D) was developed as a concept for progressing from the final actions of the Disposal Phase, through the Decontamination and Decommissioning Phase, and into the initiation of the Long-Term Monitoring Phase. This plan was written in a manner that coincides with many of the requirements specified in DOE Order 5820.2A, Radioactive Waste Management; ASTM E1 167 87, Standard Guide for Radiation Protection Program for Decommissioning Operations; and other documents listed in Attachment 3 of the D\&D Plan. However, this conceptual plan does not meet all of the requirements necessary for a Decontamination and Decommissioning plan necessary for submission to the U.S. Congress in accordance with the Land Withdrawal Act (P.L. 102-579). A complete D\&D plan that will meet the requirements of all of these documents and of the Land Withdrawal Act will be prepared and submitted to Congress by October 1997. 


\section{DISCLAIMER}

This document was prepared as an account of work sponsored by an agency of the United States Government. Neither the United States Government nor any agency thereof, nor any of their employees, makes any warranty, express or implied, or assumes any legal liability or responsibility for the accuracy, completeness, or usefulness of any information, apparatus, product or process disclosed, or represents that its use would not infringe privately owned rights. References herein to any specific commercial product, process, or service by trade name, trademark, manufacturer, or otherwise, does not necessarily constitute or imply its endorsement, recommendation, or favoring by the United States Government or any agency thereof. The views and opinions of authors expressed herein do not necessarily state or reflect those of the United States Government or any agency thereof.

This document has been reproduced directly from the best possible copy. It is available to DOE and DOE contractors at the following address:

Office of Scientific and Technical Information

P. O. Box 62

Oak Ridge, TN 37831

Prices available from (615) 576-8401

Available to the public from the National Technical Information Service

U. S. Department of Commerce 5285 Port Royal Road

Springfield, VA 22161

Processing and final preparation of this report was performed by the Waste Isolation Pilot Plant Management and Operating Contractor for the U.S. Department of Energy under Contract No. DE-AC04-86AL31950. 


\section{Table of Contents}

1.0 Site Decontamination and Decommissioning Plan $\ldots \ldots \ldots \ldots \ldots \ldots$

1.1 Facility Description . . . . . . . . . . . . . . . . . . . . 2

1.1 .1 Background ......................... 2

1.1 .2 General Plant Description ................... 3

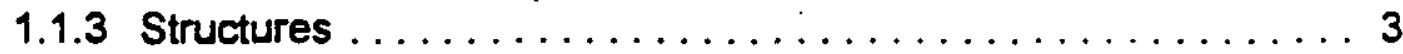

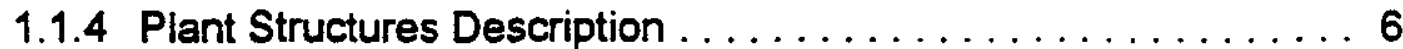

1.2 Description of Operating History $\ldots \ldots \ldots \ldots \ldots \ldots \ldots \ldots \ldots$

1.2.1 Initial Construction and Permitting $\ldots \ldots \ldots \ldots \ldots \ldots \ldots$

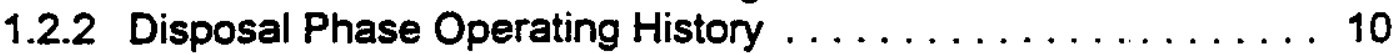

1.3 Program Objectives . . . . . . . . . . . . . . . . . . 10

1.3.1 Decommissioning Objective $\ldots \ldots \ldots \ldots \ldots \ldots \ldots \ldots \ldots$

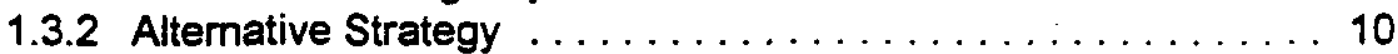

1.3 .3 Cleanup Criteria . . . . . . . . . . . . . . . . . 11

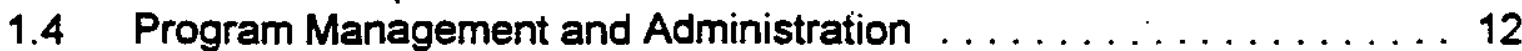

1.4.1 Organization ....................... 12

1.4 .2 Responsibilities ..................... 12

1.4.3 Decommissioning Project Team . . . . . . . . . . . . . 13

1.4.4 Decommissioning Manpower ................. 13

1.4.5 Worker Health and Safety Training ............. 13

1.4.6 Use, Control, and Management of Subcontractors . . . . . . 13

1.5 Program Schedule and Cost . . . . . . . . . . . . . . . . 13

1.5.1 Major Milestone Schedule - Narrative . . . . . . . . . . . 13

1.5.2 Cost Estimate - Narrative . . . . . . . . . . . . . . . . . 15

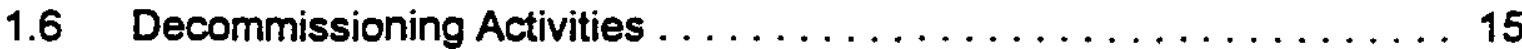

1.6.1 Plant Radiological Characterization ............. 15

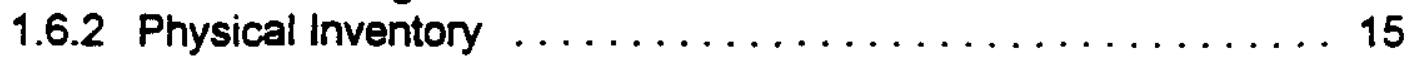

1.6.3 Facility and Site Preparation ................. 16

1.6.4 Decontamination ........................ 17

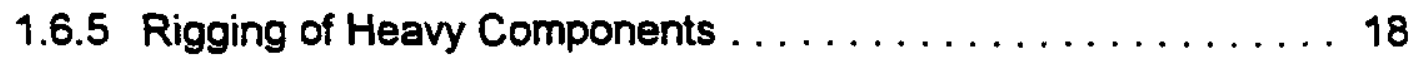

1.6.6 Liquid Radwaste Processing ................... 19

1.6.7 Solid Radwaste Handling, Packaging and Emplacement . . . . . 19

1.6.8 Nonradioactive Hazardous Waste Handling and Disposal . . . 20

1.6.9 Solid Waste Handling and Disposal . . . . . . . . . . . . . 20

1.6.10 Removal of Radioactive Equipment . . . . . . . . . . . . . 21

1.6.11 Removal of Nonradioactive Equipment . . . . . . . . . . 23

1.6.12 Removal of Power and Control Systems ........... 24

1.6.13 Removal of Contaminated Surfaces ... . . . . . . . . . . . 24

1.6.14 Closure of Last Hazardous Waste Management Unit . . . . . 25

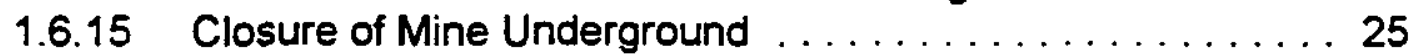

1.6.16 Shaft Sealing and Plugging $\ldots \ldots \ldots \ldots \ldots \ldots \ldots$ 


\section{Table of Contents}

1.6.17 Demolition and Removal of Structures ........... 26

1.6.18 Final Radiological Survey and Hazardous Constituent Analysis ......................... 26

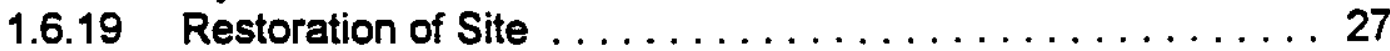

1.6.20 Facility Release and Reporting .............. 30

1.7 Facility Modification ......................... 30

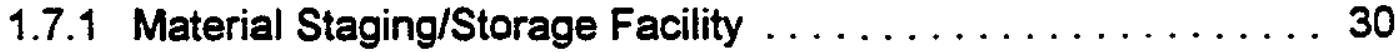

1.7 .2 Liquid Treatment Facility $\ldots \ldots \ldots \ldots \ldots \ldots \ldots \ldots \ldots . \ldots \ldots$

1.8 Waste Management .......................... 31

1.8.1 Radioactive Materials . . . . . . . . . . . . . . . 31

1.8 .2 Hazardous Materials . . . . . . . . . . . . . . . 31

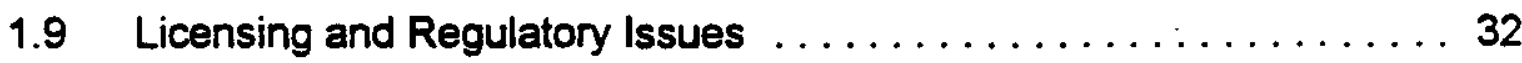

1.9.1 Regulatory Compliance ................... 32

1.9.2 Permit Modifications ....................... 33

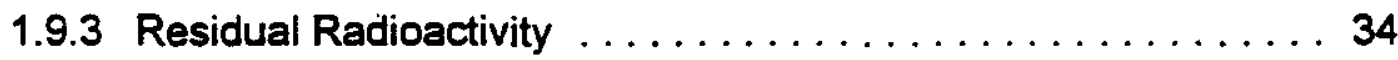

1.10 Records Disposition ........................... 34

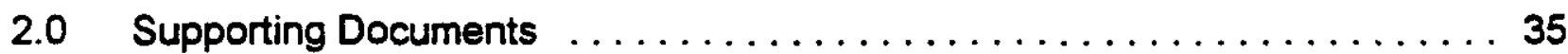

2.1 Detailed Implementation Plan ...................... 35

2.2 Engineering Plan .............................. 35

2.3 Cost, Schedule and Financing Plan ................. 35

2.4 Solid Waste Management Unit Closure Plan . . . . . . . . . . 35

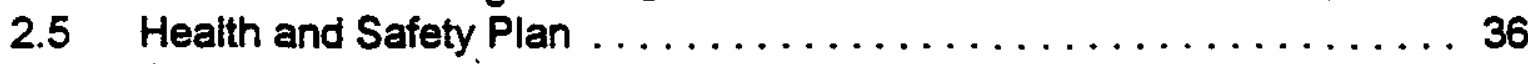

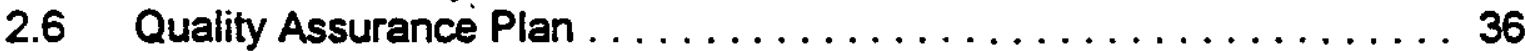

2.7 Emergency Plan .......................... 36

2.8 Environmental Report/NEPA Documentation ............. 36

2.9 Radiological Protection Plan ..................... 36

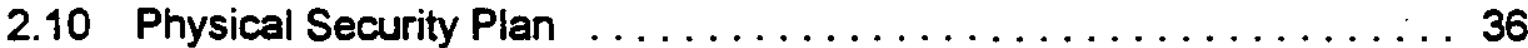

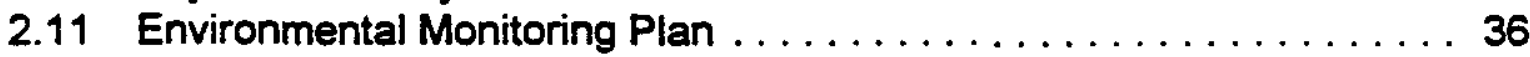

2.12 Supplemental Environmental Impact Statement $\ldots \ldots \ldots \ldots \ldots 36$ 


\title{
List of Attachments
}

\author{
Attachment $1 \quad$ Schedule \\ Attachment 2 Decontamination and Decommissioning Management \\ Attachment 3 References
}

02527 


\subsection{Site Decontamination and Decommissioning Plan}

This plan serves to describe the objectives of decommissioning for the Waste Isolation Pilot Plant (WIPP), identifies the elements necessary to accomplish the decommissioning, and defines the steps to execute those elements in a safe and environmentally sound manner.

This document is not intended to delineate the requirements necessary for Resource Conservation and Recovery Act (RCRA) closure. Where this document interfaces with those requirements, there will be guidance that directs the reader to Chapter I of the RCRA Part B Permit Application.

The Waste Isolation Pilot Plant Land Withdrawal Act of 1992 (LWA), PL 102-579, Section 13(a) requires that within 5 years after the date of the enactment of the act (enacted October 30,1992), the Secretary of Energy (herein called the Secretary) shall submit to the Congress, the State of New Mexico, the Secretary of the Interior, and the Administrator of the EPA, a plan for the decommissioning of WIPP. In addition to activities required under the Agreement (July 1, 1981, Agreement for Consultation and Cooperation, between the State of New Mexico and the U. S. Department of Energy, as amended), the plan shall conform to the disposal regulations that apply to WIPP at the time the plan is prepared, and the Secretary of Energy shall consult with the Secretary of the interior and the State in the preparation of such plan.

The plan provides a strategy for progressing from the final actions of the Disposal Phase, through the Decontamination and Decommissioning Phase, and into the initiation of the Long-Term Monitoring Phase.

This plan describes a sequence of events for decontamination of the WIPP facilities and structures used to manage and contain TRU and TRU mixed waste during the receipt and emplacement operations. Alternative methods of decontamination are provided where practical. The methods for packaging and disposal of the waste generated (derived waste) during this process are discussed. The best available technology at the time of this plan's development, may become outmoded by future technology and altemative strategies. If alternative technologies are identified the affected stakeholder(s), the Secretary of the Interior and the State will be consulted prior to implementation.

Dismantling of the WIPP major structures will be detailed in specifications separate from this plan for each structure.

The disposal of uncontaminated equipment and residue is delineated in Sections 1.6.9, and 1.6.11. Radioactively contaminated and mixed wastes that meet the waste acceptance criteria for decontamination and decommissioning (DD-WAC) will be emplaced into the last Hazardous Waste Management Unit (HWMU) open in the underground. At the WIPP, HWMUs are designated as the combination of waste disposal rooms and connecting drifts that form a panel. Each panel is an HWMU. Equipment, structures, materials, and components will be decontaminated whenever 
possible. Residues that meet the definition of "construction and demolition debris,"("Construction and demolition debris' means materials generally considered to be not water soluble and nonhazardous in nature, but not limited to, steel, glass, brick, concrete 3 sphalt roofing materials, pipe, gypsum wallboard and lumber from the construction or destruction of a structure project, and includes rocks, soil, tree remains, trees and other vegetative matter that normally results from land clearing. If construction and demolition debris is mixed with any other types of solid waste, it loses its classification as construction and demolition debris. Construction and demolition debris does not include asbestos or liquids including but not limited to waste paints, solvents, sealers, adhesives or potentially hazardous materiais." SWMR-4, Section 105, Paragraph T) that are free of contamination may be disposed in a Construction Landfill. Mined salt remaining after closure and berm construction will be disposed under Sections 2 and 3 of the Minerals Act of 1947.

Other activities necessary to return the site to as near its original condition as possible are defined in Section 1.6.19.

Generally, stakeholder involvement in the decontamination and decommissioning activities, as well as socioeconomic impacts to the local communities, counties, and state will be provided in the appropriate National Environmental Policy Act (NEPA) documentation for decommissioning.

\subsection{Eacility Description}

\subsubsection{Backoround}

The U. S. Department of Energy (DOE) was authorized by the Department of Energy National Security and Military Applications of Nuclear Energy Authorization Act of 1980 , Public Law 96-164 (U. S. Congress, 1980) to develop a facility for demonstrating the safe disposal of transuranic (TRU) radioactive wastes generated as the result of national defense activities. This facility, known as the Waste Isolation Pilot Plant, has been constructed in southeastern, New Mexico, 26 miles east of the City of Carlsbad. The site encompasses 10,240 acres in a sparsely populated area. Land use in the area surrounding the WIPP land withdrawal area includes livestock grazing, potash mining, and oil and gas production.

The enactment of Public Law 96-164 authorized the continuation of the phased development of the WIPP. Phased development began with a siting phase during which several sites were evaluated and a preferred site was selected based upon the geological and hydrological factors. During this phase, the host rock and the depth of the facility were selected considering geologic, hydrologic, geochemical and rockmechanics properties. In the next phase, the site and preliminary design validation phase, two shafts were constructed; an underground testing area was excavated; and geologic, hydrologic, and geotechnical investigations were continued to gain further information on the site's characteristics. Also during this phase, methods for assessing long-term performance were evaluated and advanced. The construction phase followed during which the WIPP facility was constructed, additional data about the site 
were collected, and the tools needed for assessing performance were developed and refined. Surface structures were built and additional underground areas were excavated for further experimentation. At the conclusion of the construction phase, the DOE proposed to proceed into a test phase that would include testing with TRU waste.

In October 1992 Congress transferred jurisdiction of the land from the Secretary of the Department of the interior to the Secretary of the DOE and reserved the land for use by the DOE for the WIPP Program. The LWA also provided additional authorization to continue the activities initiated by Public Law 96-164. The LWA requirements focus on the test phase and the criteria for certification of compliance with the long-term disposal regulations developed by EPA. In late 1993 the DOE announced that the WIPP would not conduct radioactive tests in the WIPP underground. While testing with radioactive waste will not be conducted at the WIPP, many requirements such as development of certification criteria by the EPA, and other requirements necessary to begin disposal are still applicable and are covered in several other documents.

\subsubsection{General Plant Description}

The waste will be disposed in Hazardous Waste Management Units (HWMU) located 2150 feet below the surface of the WIPP site in bedded salt. The facility capacity is limited to 6.2 million $\mathrm{ft}^{3}$ of contact handled $(\mathrm{CH})$ and remote handled $(\mathrm{RH})$ TRU wastes many of which are aiso contaminated with hazardous waste. The RH waste is currently planned to be emplaced in the ribs of the excavated rooms and the $\mathrm{CH}$ waste is to be stacked in the excavated rooms.

As each HWMU is filled, the access drifts will be closed to prevent access by personnel and to decrease the potential for release of contaminants. The last HWMU will have space available for acceptance of decontamination waste generated (derived waste) during the execution of this plan.

Descriptions of topography, soils, geology, demography, meteorology, radiological and hazardous materials characteristics, radionuclide inventory, and environmental characteristics are available in the Draft Waste Isolation Pilot Plant Project Technical Baseline for Regulatory Compliance (Reference 54).

\subsubsection{Structures}

All structures will require removal of office furnishings, telephone service, site computer network, plumbing fixtures and piping. HVAC, electrical service, structure and foundation. Several structures will require the removal of compressed air, large equipment, fluid lines, etc. Removal specifications will be developed for each structure.

The Hot Cell in the RH portion of the Waste Handling Building may remain as part of the permanent marker system. Modifications to the structure may be required if it is determined that it will remain as an artifact. Such modifications will require engineering development. 


\subsubsection{Plant Structures Description}

The WIPP is divided into three basic groups of structures; surface structures, shafts, and underground structures.

The WIPP facility surface structures accommodate the personnel, equipment, and support services required for the receipt, preparation, and transfer of waste from the surface to the underground. The surface structures (excluding Port-a-camp, various storage areas, microwave tower, sewage treatment system, wells, pipeline, power line, access roads, environmental monitoring stations, landfills, Building 471 [Northwest Atmospheric Monitoring Station], Building. 472 [Instrument Building.] and roadbeds) are located in an area of approximately 35 acres within a perimeter security fence.

The primary surface operations at the WIPP facility are conducted in the Waste Handling Building (WHB), which is divided into several separate waste management areas. These areas include, the CH TRU waste handling area, the RH TRU waste handling area, the transuranic package transporter (TRUPACT-II) maintenance facility, and support areas.

The $\mathrm{CH}$ TRU waste handling area includes an outdoor truck loading and offloading area, a shielded storage room, an inventory and preparation area, and an overpack and repair room.

The RH TRU waste handling area includes: a shipping and receiving area; a shielded cell for shipping cask unloading, waste canister inspection, overpacking canisters, as required; a canister transfer cell; and facility cask loading.

The TRUPACT-II maintenance facility is a radiologically clean dedicated area, adjacent to the CH TRU waste side of the WHB. Decontamination of a TRUPACT-II, if required, would be accomplished in the CH TRU waste side of the WHB.

Other areas within the WHB include: a site-derived waste area; heating, ventilation, and air conditioning (HVAC) equipment area; and mechanical equipment areas.

The site-derived waste area, located in the WHB, is provided for the handling of waste produced on the site as a result of decontamination operations. Waste water collection from fire main activation in the CH TRU side of the WHB will collect in a sump located in the site-derived waste room. Waste water from fire main actuation in any area with potential contamination (radioactive and/or hazardous) will be reacted to under the Hazardous Materials Spill Response section of the Emergency Services Program Plan (Reference 77).

The WIPP surface structures include the Exhaust Filter Building, Engineering Building, Training Building, Support Building, Safety and Emergency Services Facility, Warehouse buildings, Guard and Security Building, Vehicle Service Building, a sewage treatment plant, underground fuel storage tanks (USTs), and other auxiliary buildings. 
The Exhaust Filter Building contains banks of high efficiency particulate air (HEPA) filters that will be used to filter contaminated air from the underground in the unlikely event of a release. The underground ventilation system fans are located outside, adjacent to this building.

The Support Building provides office space, change rooms, and houses the Central Monitoring Room (CMR) and its supporting equipment.

The WIPP is accessible by both road and railway. Access to the site is from U.S. Highway 62/180, about 13 miles to the north, and from Highway 128 , four miles to the south. Rail access is provided by a rail line connecting with a spur of the Atchison, Topeka, \& Santa Fe railroad six miles southwest of the site.

WIPP has four vertical shafts that extend from the surface to the underground horizon. These are: the Waste Shaft, the Salt Handling (SH) Shaft, the Exhaust Shaft (ES), and the Air intake Shaft (AIS).

The SH shaft is steel lined to the top of the salt formation (about 850 feet below the surface) and the other shafts are lined with concrete to the top of the salt formation.

The Waste Shaft is located between the CH TRU and RH TRU areas in the WHB. It is nominally 19 feet in diameter and is serviced by a hoist utilizing a hoist cage that is primarily used for transportation of CH TRU and RH TRU wastes from the surface to the underground storage areas. This shaft is also used to transport personnel, materials and supplies, and large equipment.

The SH Shaft is located beneath the salt handling headframe. It is nominally 10 feet in diameter and has a combined mancage/bottom dump salt handling skip. This shaft provides the only means of removing mined materials from the underground. It serves as the secondary ventilation supply shaft for the underground areas. The SH shaft is a route for power, control, monitoring and communication cables. Personnel can also be transported in this shaft.

Salt from the underground mining operations is brought to the surface via the Salt Shaft and stored in the salt pile north of the surface facilities.

The exhaust shaft is located adjacent to the Exhaust Filter Building. It is nominally 14 feet in diameter and serves as the exhaust air duct for the underground areas.

The underground ventilation system consists of five centrifugal exhaust fans, two parallel HEPA filter assemblies, isolation dampers, filter bypass, and associated ductwork. The two main exhaust fans provide unfiltered flow of up to 425,000 cubic feet per minute for normal underground operations. Three filtration fans can each provide 60,000 cubic feet per minute during filtration mode or reduced ventilation mode. Continuous Air Monitors (CAMs) are installed to detect airborne radioactive contaminants in the waste disposal area, the Waste Shaft and station, and in the discharge to the surface discharge stack. One alarm from the Station A Effluent 
Sampling System or an alarm received from two like CAMs (two alphas or two beta/gammas) will cause automatic activation of the HEPA filtration system.

The AIS is located to the west of the warehouse. It has three diameters ( 18 feet concrete lined, 16 feet 7 inches concrete lined and 20 feet 3 inches unlined salt section) and is the primary supply of fresh air underground.

The underground structures are located on the storage horizon and consist of the waste storage area, the experimental area, the mining area, and the waste shaft station.

The waste storage area has four main entries, a number of crosscuts connect the main entries. The layout of the shafts and entries permits mining and storage operations to proceed simultaneously. New hazardous waste management panels will be mined as the preceding panel is filled with waste.

Each waste storage panel will consist of seven rooms. Each room is nominally 33 feet wide by 300 feet long by 13 feet high. The storage rooms are separated by salt pillars 100 feet wide by 300 feet long. The first 200 feet of each panel is 20 feet wide and 13 feet high to facilitate the closure of each panel. After the initial 200 feet the panel is widened out to 33 feet.

The waste shaft station located at the lower end of the waste shaft provides access for personnel and equipment to handle the waste.

Workshop and warehouse facilities are located at the storage horizon. Shops consist of a repair bay, a welding bay, a lubrication bay, an electrical shop, several parking areas, and a warehouse. Offices, electrical substations, and lunch rooms are also located at the storage horizon.

The experimental area of the mine used for experiments using simulated wastes and for geotechnical evaluations consists of several rooms and pillars that are used to perform rock mechanics tests, waste package and waste form experiments, and brine migration tests. In part, tests provided information used in room and pillar design of the waste storage area and support Performance Assessment activities/validation.

\subsection{Description of Operating History}

\subsubsection{Initial Constnuction and Permitting}

Development of the WIPP facility began with a siting phase (in 1973), during which several sites were evaluated and the present site was selected on the basis of extensive geotechnical research, supplemented by surface-based testing. Based upon the geologic properties of the selected site, the repository was designed and safety analyses were prepared. Subsequent research expanded the understanding of the geologic, hydrologic, geochemical, and rock-mechanics properties of the host rock and surrounding strata at the site. The siting phase ended with the publication of a Final 
Environmental impact Statement (FEIS) (Reference 20) in 1980 and associated Record of Decision (ROD), which evaluated alternatives for the safe, long-term isolation of TRU waste at the WIPP facility.

The construction phase followed, authorized by Public Law 96-164 (Reference 38) during which surface structures for receiving waste were built and underground excavations were completed for one panel of rooms designed for permanent waste emplacement. The DOE and the State of New Mexico entered into a Consultation and Cooperation Agreement (Reference 43) to affirm the intent to give consideration for concerns and cooperation in the resolution of those concerns. The end of the construction phase was marked by a decision by the DOE Energy Systems Acquisition Advisory Board (ESAAB), after all prerequisites for ending construction were met and documented (in 1991). These documents used the data collected since 1980 to evaluate the potential short-term and long-term impacts of the WIPP facility. In 1992 the Final Safety Analysis Report (FSAR) (Reference 49) was published.

At the conclusion of the construction phase, the DOE proposed to proceed into a test phase that would include testing with TRU and TRU mixed waste at the WIPP facility. Although the DOE has made the decision not to conduct underground tests with radioactive wastes in the WIPP facility, information regarding a compliance demonstration has not changed and this experimental data is being collected at the Idaho National Engineering Laboratory.

Upon a successful demonstration of compliance with applicable federal and state laws and regulations, and once the certification and approval requirements of the LWA are met, the WIPP facility will proceed through three other distinct phases: a disposal phase, a decommissioning phase, and a post-decommissioning phase. The disposal phase, projected to last 25 years, will consist of receiving, handling, and emplacing TRU and TRU-mixed waste in the repository for disposal. Additional scientific studies may continue during the disposal phase. The disposal phase will end when a decision is made to terminate further disposal activities or the repository has reached its capacity.

The decommissioning phase will follow the disposal phase. During the decommissioning phase the facility will be decontaminated and prepared for permanent closure. Closure of the HWMUs will be performed in accordance with the direction of Chapter I of the RCRA Part B Permit application. Surface facilities will be decontaminated and decommissioned, underground excavations will be closed, and shaft seals will be emplaced. This phase is projected to last eight years, with six years estimated for the RCRA closure portion.

The post-decommissioning phase will include the implementation of active and passive institutional controls. Active institutional controls may include activities such as longterm site access control and post-closure monitoring. Such controls will be implemented consistent with applicable regulations and permit conditions. Passive institutional controls will include notification devices such as permanent markers designed to reduce the likelihood of human intrusion, archival storage of WIPP 
information off-site, and large earthen structures marking the repository footprint on the surface. The concept for permanently marking the WIPP, as required by Title 40 CFR 191.14(c), is described by a draft report listed in Attachment 3 (Reference 37).

\subsubsection{Disposal Phase Operating History}

As of this revision to the Conceptual Decontamination and Decommissioning Plan there is no disposal phase operating history.

\subsection{Program Objectives}

\subsubsection{Decommissioning Objective}

The main objective of decommissioning the WIPP site is to return the site to as close to the pre-construction condition, as reasonably possible, while protecting human health, the environment, and to meet NEPA and WIPP Land Withdrawal Act commitments.

\subsubsection{Altemative Strategy}

The decommissioning alternatives rejected in the Final Environmental Impact Statement included mothballing and in-place entombment.

These alternatives allowed for decommissioning the plant under the following credible situations:

- Decommissioning after the repository has been filled. The preferred methods would be in-place entombment of unusable underground structures, decontamination (as required), and dismantling of the surface structures.

Decommissioning before the repository is filled, leaving open the possibility of later returning to fill it. Mothballing of the surface structures would be the preferred method for this situation. Due to creep closure the underground areas would require mining to obtain a safe work environment.

The present plan calls for decontaminating (as required) and dismantling surface facilities, entombing in the waste-disposal area all wastes generated in dismantling the surface facilities if they meet DD-WAC, close the remaining mine, and sealing the shafts and boreholes. Any wastes that do not meet the DD-WAC will be transported to an approved and permitted off-site facility.

Mothballing would consist of putting the plant into a state of protective storage for a few decades. This altemative would be selected if later repository operation or experiments were desired. It would require the eventual use of another alternative for the permanent decommissioning of the plant. The plant would be left generally intact except that all areas with hazardous levels of radiation would be isolated from the 
public by suitable barriers and other means. Useful equipment could be decontaminated, if necessary, and removed from the site. Adequate radiation monitoring, environmental surveillance, and security procedures would be established to protect the health and safety of the public. The shafts and underground facilities would be left intact. This alternative was rejected.

Entombment applies mainly to the shafts and mine. Entombment of the surface facilities would be similar to mothballing except that the radioactive materials would be removed and placed in the mine or removed from the site. After the removal of usable equipment (and decontamination, if necessary), the vacated mine would be closed, and the shafts and boreholes would be sealed. In this alternative the mine and shafts would be permanently sealed; the surface facilities, however, would be available for some other use in the future. This alternative was rejected.

Decontamination and dismantling would involve the surface facilities, with the shaft and mine entombed as described above. Usable equipment would be decontaminated and removed; contaminated equipment and waste would be packaged and either placed in the mine or removed from the site if mine disposal were not feasible. Surface facilities would be demolished and debris removed or buried in the Construction and Demolition landfill. As nearly as possible, the surface would be returned to its original condition.

\subsubsection{Cleanup Criteria}

Criteria for the mixed waste decontamination is defined in 40 CFR 264, Subpart GClosure and Post-Closure; WIPP RCRA Part B Permit Application, DOENIPP 91-005, Chapter $\longmapsto$ Closure Plans, Postclosure Plans, and Financial Requirements, 20 New Mexico Administrative Code (NMAC) 4.1 Subpart V, Subparts G, I, and X, and DOE Order 5820.2A, Radioactive Waste Management.

Because of the type of waste management activities that will occur at the WIPP facility, waste residues that may be encountered during the operation of the facility and at closure may include waste generated as a result of the management of the waste containers (derived waste including rags and rubber gloves), waste generated as part of the closure activities (such as wipes used to sample the containers and equipment for potential radioactive contamination, solidified decontamination solutions, stabilized concrete dust from scabbler operations, equipment designed for disposal, contaminated salt that is excavated because of decontamination activities, etc.), and residues generated as a result of spill cleanup (rags, gloves, hazardous materiais). All of the above wastes generated (derived wastes) during the operation and closure of the WIPP facility will be identified and managed as TRU mixed wastes.

Criteria for the radiological portion of the mixed waste decontamination is defined in DOE Order 5820.2A (Reference 22).

On the basis of "co-detection of hazardous and radioactive releases," decontamination will be considered complete for RCRA constituents when radiological decontamination has been accomplished. Radiological decontamination will be to less than or equal to: 


$\begin{array}{lll} & \text { Leose } & \text { Fixed plus Removable } \\ \alpha & 20\left(\mathrm{dpm} / 100 \mathrm{~cm}^{2}\right) & 500\left(\mathrm{dpm} / 100 \mathrm{~cm}^{2}\right) \\ \beta-\gamma & 200\left(\mathrm{dpm} / 100 \mathrm{~cm}^{2}\right) & 1000\left(\mathrm{dpm} / 100 \mathrm{~cm}^{2}\right)\end{array}$

All surveys for contamination at the WIPP facility are based on the concept of codetection. Co-detection is used to describe the detection of releases from containers by virtue of detection of radioactive contamination. Co-detection applies to all releases except the release of VOCs from TRU mixed waste containers. It provides the WIPP facility with a very sensitive method of detecting the release of non-VOC hazardous TRU constituents through the use of surface sampling (swipes) and radioactivity counting.

Decontaminated materials and equipment must be sampled in accordance with applicable procedures to assure that there are no RCRA constituents beyond the levels authorized for release. Items that are found to exceed the limits will be properly packaged and transferred to an appropriate treatment storage and disposal facility.

\subsection{Program Management and Administration}

\subsubsection{Oroanization}

A graphic representation of the management and operating contractor decontamination and decommissioning management organization is presented as Attachment 2.

\subsubsection{Responsibilities}

Decommissioning Project Manager - provides overall management of the decontamination and decommissioning effort. As the facility converts from the operational phase to the decommissioning phase, overall responsibility for the project management will shift to this individual.

Engineering Manager - provides engineering support for all D\&D activities. Provides management oversight for licensing and regulatory compliance activities.

Construction Manager - provides control of maintenance activities, decommissioning utilities, structure removal, and shaft seal installation.

Operations Manager - provides management of radiological and chemical decontamination activities, mine closure process, facility operations, health physics, and environmental monitoring operations.

Administrative Manager - provides control of the budget and schedule, directs procurement activities, manages human resources, and manages training.

Safety/Security Manager - provides the overall safety oversight of the D\&D activities. Provides for the physical security of the WIPP site. 
QA Manager - identifies, develops and defines quality requirements applicable for the D\&D process. Consults with line management in interpreting and implementing quality program elements, and provides performance-based independent assessment of quality affecting activities.

\subsubsection{Decommissioning Project Team}

The Decommissioning Project Team consists of the Department of Energy and the management and operating contractor.

\subsubsection{Decommissioning Manpower}

Decontamination and decommissioning process manpower will be developed from the WIPP workforce. As the operational phase is completed, personnel without proper job skills will be cross-trained for the new positions being created by the decommissioning phase. This process will reduce the need for layoffs, and provide a knowledgeable and experienced workforce.

\subsubsection{Worker Health and Safety Training}

Worker training for health and safety will be conducted in accordance with 29 CFR 1910.1200 and other applicable regulations. The basic training will be accomplished through the general employee training course administered to all new employees and with annual refresher training for all employees.

For further information on training policies refer to the current procedures listed in Attachment 3 of this plan (References $3,83-85$ ).

Personnel will continue to qualify and maintain qualification on the systems and equipment that they will operate.

\subsubsection{Use. Control. and Management of Subcontractors}

Current procurement policies and procedures for subcontractor interface are listed in Attachment 3 of this plan (References 65, 85-87).

\subsection{Program Schedule and Cost}

\subsubsection{Maior Milestone Schedule - Narrative}

A schedule of the D\&D process is included in this document as Attachment 1.

Acquire permits and approvals for D\&D activities.

Removal of equipment and closure of the underground experimental areas may commence as soon as the area is no longer required. 
As personnel downsizing takes place, temporary surface structures will become empty, and removal may commence.

Removal of temporary surface structures will be initiated prior to the projected emplacement of the last shipment of waste.

A site radioactivity characterization study will be performed to determine what areas of the site will require decontamination, to facilitate selection of an appropriate decontamination and decommissioning strategy, and after the decommissioning, demonstrate that the residual radioactive and/or hazardous materials satisfy criteria for unrestricted release.

Excess underground equipment will be decontaminated if required, moved to the surface, and disposed of in accordance with applicable federal property management regulations (41 CFR 101).

When economically feasible all usable equipment and materials will be decontaminated and removed from the site. Surface facilities will be decontaminated as required.

Contaminated structural debris, equipment, and decontamination wastes that meet the DD-WAC, will be packaged and placed in the mine in the last panel. Decontamination will be performed using technologies that do not add materials which would cause the derived waste to violate the DD-WAC. Liquids and fine particulate would require stabilization prior to disposal in the mine. Perform closure of the last HWMU in the same manner as the other panels. As the mine is closed the equipment will back out and be removed.

Shafts will be sealed in accordance with acceptable techniques.

Each Solid Waste Management Unit (SWMU) will be closed in accordance with all applicable regulations and requirements when it is no longer required.

Dismantling of surface facilities will commence upon vacancy and completion of radiological survey and, if required, decontamination.

Uncontaminated debris and unusable equipment will either be shipped away from the site for disposal or disposed of in the construction and demolition landfill.

Decommission the sewage system and the NPDES storm water evaporation basins. Close all SWMUs.

Excess salt will be disposed of per the Minerals Act of 1947.

Electrical power, telephone lines, water, railroad spurs, and roads will be removed, as required (electrical power, RR spurs and roads should remain to the degree necessary to support future construction of the Permanent Marker System and Permanent Marker testing). 
The surface will be regraded to approximately its original contours.

Markers will be provided consistent with the approved passive control strategy.

Monitoring and active control will be established.

Unneeded environmental monitoring stations will be removed.

The underground storage tanks used for the storage of fuels will be removed in accordance with applicable regulations.

A final decommissioning report will be developed.

\subsubsection{Cost Estimate - Narrative}

A cost estimate will be developed for these activities for the Decontamination and Decommissioning Plan required by the Land Withdrawal Act. A conceptual cost estimate is available from the Waste Isolation Division Long-Term Regulatory Compliance group.

\subsection{Decommissioning Activities}

\subsubsection{Plant Radiological Characterization}

Extensive radiological contamination surveys of all areas of the WIPP site will be performed. The results of these surveys will provide the basis for selection of technology for decontamination and decommissioning of the WIPP facilities. Along with the historical records of surveys performed during the operational life of the facility, the contamination surveys will provide evidence for release of structures, equipment, and components.

\section{Radiological Survey and Sampling Program}

The radiological survey and sampling program will be accomplished using current procedures listed in Attachment 3 of this plan (Reference 74).

\subsubsection{Physical Inventory}

A complete inventory of all site facilities, equipment, and assets is to be performed so that disposition requirements may be determined prior to the items becoming excess. This inventory is standard practice for every major facility change.

\section{Facility Physical Inventory}

This inventory can be accomplished utilizing the WIPP Site Facility Master Plan (Reference 2). This is a controlled drawing, which coupled with outstanding Engineering Change Orders provides a complete listing of the site facilities. 


\section{Site Physical Inventory}

Property Management maintains a database of all site equipment valued at $\$ 1000$ or more, all real property regardless of value, and sensitive items valued at $\$ 200$ and above. This database includes information such as the Manufacturer's nomenclature and model/serial number(s), the date the equipment was put into service, purchase order number and depreciable life, etc.

\subsubsection{Facility and Site Preparation}

Individual specifications will be developed for each structure prior to removal. These specifications will include a statement of work, as-built drawings, construction specifications, disposition of materials, required worker training and qualifications, etc. Specific instructions can be found in current WIPP procedures listed in Attachment 3 of this plan (References 86, 87).

\section{Temporary Structures}

Temporary structures such as the trailers used for offices will be prepared for disposal following vacancy and radiological clearance. Utilities (power, telephone, water, sewage, computer network, alarms, etc.) will be removed by site personnel. Office equipment and furniture removal may be contracted. The removal of skirting, reinstallation of axles, and towing may be performed under contract.

\section{Laydown Areas}

Laydown areas will be designated for radiologically contaminated materials, hazardous waste, solid waste, and scrapped or salvaged equipment/materiais. These areas should be located centrally to where the majority of work is to be performed. Hazardous waste will be collected, accumulated, and disposed in accordance with applicable regulations.

\section{Support Services}

- Power will be maintained from the SPS feed east of the site. No conversion to construction power will be necessary to perform structure removal.

- Telephone service will continue through the telephone hut until the size of the site makes it no longer economical to maintain the hut, at which time the GTE telephone service will be transferred to individual feeds.

- Water is supplied by the Double Eagle Water Line, owned by the City of Carisbad, through their wells located approximately 30 miles north of the WIPP. Water is supplied by gravity flow through a 24-inch diameter pipeline to a junction point about 13 miles north of the site at $U . S$. Highway $62 / 180$. This line is sized to provide $6000 \mathrm{gal} / \mathrm{min}$ for use by 
others in addition to the peak flow rate required by the WIPP facility. Controls at the junction point give the WIPP facility priority over flows to all other users. A 10-inch diameter pipeline supplies $375 \mathrm{gal} / \mathrm{min}$ water flow from the tie in point to the WIPP facility by gravity flow.

The water supply to the site will continue until such time that the domestic and fire water requirements no longer exist. At that time the pipeline will be capped. Ownership of the waterline will be transferred to the City of Carisbad. The portion of the pipeline that the City does not want, will be decommissioned and removed.

- $\quad$ Refuse removal will continue with contractor support until the facility is taken into the post-decommissioning long-term monitoring phase.

- Sewage treatment is currently performed in a series of settling treatment and evaporation ponds south of the site. When the number of personnel has decreased enough that the need for these ponds is no longer necessary, and may be supplanted by portable facilities, the ponds will be closed in accordance with applicable regulations.

\subsubsection{Decontamination}

The "Start Clean - Stay Clean" operating philosophy of the WIPP site will decrease the need for decontamination during the Decommissioning phase. However, the need for decontamination technology may arise.

\section{Chemical Cleaning}

Detergents - no detergents are currently planned for use in decontamination activities.

Solvents

Water in limited quantities (e.g. dampened rags) - is the primary solvent used for decontamination

Windex - may be used on a limited basis

Radiacwash - may be used only if water, Windex reducing contamination to acceptable release levels.

\section{Nonchemical Decontamination}

Polyvinyl Alcohol - is used to remove radiological contamination from smooth surfaces such as the waste handling building floor. The residue from this process is a solid plastic contaminated with radioactive material and hazardous waste. The residue of the Polyvinyl Alcohol may be disposed of in the underground as a mixed waste. 
Sandblasting - this method of decontamination would create large quantities of contaminated waste for disposal and is not recommended.

Grinding - this method would create a smaller quantity of contaminated waste than sandblasting, and might be used in limited applications.

High-Pressure Water Spray - this method could create large volumes of water that would need to be treated or stabilized before disposal and is not recommended.

Scabbler Pistons and Needle Scalers - this method utilizes pneumatically operated reciprocating scabbler pistons and needle scalers to remove up to $3 / 16$ inch of the concrete surface which is filtered and stored in the vacuum system prior to solidification and disposal.

Ice-blast Technology - uses compressed air and ice chips to remove loose or fixed plus removable radioactive contamination, with only 24 gallons of waste water per hour of operation.

Dry ice Blasting - on impact, dry ice pellets sublimate from their solid state into gas, leaving only the removed contaminant for disposal. The process is practically nonabrasive on all surfaces, inert and non-conductive.

\section{Partial Removal of Components}

Partial removal of components will be performed when it is radiologically safe to remove a section of pipe, ventilation ducting, bracket, etc., when the larger component is not contaminated, and when the removal of a portion of the whole will significantly reduce the volume to be emplaced in the last panel.

\section{Cost/Benefit Analysis}

A cost/benefit analysis will be necessary for evaluation of the decontamination options in the event that the need for this technology arises. It is, however, too early as of this writing to make an estimate of the necessity for decontamination technology beyond that currently available at the WIPP site.

\subsubsection{Rigaing of Heavy Components}

The Department of Energy Hoisting and Rigging Manual, DOE/ID-10500 (Reference 20), will be utilized in all hoisting and rigging operations conducted at the WIPP site during decommissioning. The manual quotes verbatim or paraphrases the requirements of the Occupational Safety and Health Administration and the American National Standards Institute. It was developed to encompass, under one cover, hoisting and rigging requirements, codes, standards, and regulations. In doing so, it eliminates the need to maintain extensive (and often incomplete) libraries of hoisting and rigging standards throughout the DOE. 


\subsubsection{Liquid Radwaste Processing}

\section{Present Capacity and Capability}

There is currently no large scale capability for liquid radwaste processing at the WIPP facility. Depending on the type of decontamination equipment selected and the quantity of waste liquid created by that equipment, a decision will have to be made at a later date for this system's specifications.

Small quantities of liquid radwaste can be solidified using Aquaset(B) or an equivalent grade absorbent material.

\section{Services to be Added}

No new services are anticipated. Due to the small quantities of liquid waste that is anticipated during the decontamination and decommissioning of the WIPP, no additional equipment is deemed necessary at this time. If quantities should be greater than currently anticipated, then the following technologies may be utilized.

- Mobile Evaporators

- Demineralizers

- Mobile Solidification System

\subsubsection{Solid Radwaste Handling. Packaging and Emplacement}

\section{Containers}

Waste containers for emplacement in the WIPP shall be noncombustible and meet all applicable requirements of 49 CFR $\$ 173.412$ for Type A packaging. Waste containers of various sizes, shown to meet Department of Transportation Type A requirements by methods detailed in DOE Evaluation Document for DOT 7A Type A Packaging. DOE/DP/O0058-H1;MLM 3245 are acceptable at the WIPP.

\section{Packaging}

Waste packaging is included in the information for containers in the above subsection.

\section{Emplacement}

Decommissioning waste will be emplaced in the underground, utilizing approved waste handling operations procedures, in the last HWMU prior to closure of the unit. Containers that are not the standard waste box or 55-gallon drums, will require separate procedures to ensure that the containers are loaded into the panel in a safe and coordinated manner. 


\section{Interim Storage/Staging}

No areas within the facility are being permitted as interim storage areas. Satellite accumulation area regulations will apply. See 40 CFR 262.34 for limitations on quantities, time, and methodology for accumulation of hazardous waste at the decommissioning site. Waste containers with radioactive mixed waste will remain at the location of decontamination effort until the container is filled or the decontamination at that location is completed. As decontamination progresses beyond the surface, the waste containers will be directly emplaced in the panel. Once a container of waste is filled, it will be moved to the storage area and emplaced in a prompt manner.

\subsubsection{Nonradioactive Hazardous Waste Handling and Disposal}

The handling and disposal of nonradioactive hazardous waste will be performed in accordance with applicable regulations and approved WIPP hazardous waste management procedures. There are approved procedures in place at this time (References 46, 55, 57).

\section{Waste Packaging Process}

Current WIPP procedures listed in Attachment 3 of this plan delineate the responsibilities and handling requirements for site generated nonradioactive hazardous waste at the WIPP (References $46,55,57$ ). The waste packaging process is designed to protect human health and the environment from negative effects of hazardous waste by ensuring that hazardous waste is properiy handled, accumulated, and transported to an approved off-site treatment/storage/disposal facility in accordance with all applicable local, state and federal regulations, DOE Orders and WID policies and procedures.

\section{Transportation}

Current WIPP procedures as listed in Attachment 3 of this plan delineate the responsibilities and requirements that provide for the shipment of nonradioactive hazardous materials by the Waste Isolation Division (WID) from the WIPP, in compliance with the DOE requirement for management of materials transportation as specified in DOE Order 1540.1A, and applicable laws and regulations related to the shipment of hazardous materials (References 21,55 ).

Instructions for the on site transportation of hazardous material, hazardous waste and non-RCRA regulated material are provided in current WIPP procedures listed in Attachment 3 of this plan (Reference 57).

\subsubsection{Solid Waste Handling and Disposal}

Guidelines for the operation of the construction and demolition landfill in a manner which is protective of human health and the environment and ensures compliance with applicable local and state laws and regulations are contained in current WIPP procedures listed in Attachment 3 of this plan (Reference 56). 


\section{Identification of Laydown Areas}

The primary laydown area for solid waste (other than construction landfill debris) will be designated on the asphalt pad southeast of the Waste Handling Building.

Construction and demolition debris will be moved directly to the construction landfill.

\section{Traffic Management of Waste Site}

No scavenging will be allowed at the waste site. Prior to loading of vehicles for transport to the landfill, the waste will be characterized by process knowledge or sampling to not contain any hazardous wastes.

\section{Local Registered Sanitary Landfill Site}

The registered sanitary landfill site utilized by the WIPP site is currently located near Hobbs, NM. The landfill is not currently permitted, but will have a permit hearing in January 1995, permit submittal in June 1995, and approval is expected eighteen months following submittal.

\section{Compaction}

There is currently no requirement for compaction of the solid waste.

\subsubsection{Removal of Radioactive Equipment}

All equipment will be checked for the presence of radioactive contamination. If radioactive contamination is detected, the contaminated equipment will be assumed to be contaminated with the hazardous waste constituents of the waste in the containers that the equipment contacted. Contaminated equipment will be decontaminated to the clean limits specified in Section 1.3.3 of this document or placed in containers and managed as derived TRU mixed waste.

\section{Isolation of System and Cutting of Pipe}

The WIPP does not have piping systems that will carry radioactive materials. The closest approximation would be possible contamination of the air handling ductwork in the waste handling building. In the event that the site radioactive characterization or a routine survey detects contamination in any of the ductwork, specific work instructions will be developed for the decontamination and removal of that ductwork. Those instructions will be based on the level and extent of contamination found, using standard industry practices.

\section{Exhaust Filter Building and HEPA Filters}

The Exhaust Filter Building (EFB) and HEPA Filters associated with the EFB must be operable during underground ventilation. Emplacement of contaminated EFB HEPA filters requires underground ventilation. 
Procedures will be developed to ensure that the following steps will be performed:

a. Underground operation will be halted

b. the EFB HEPA filters will be removed

c. If the EFB HEPA filters are contaminated beyond acceptable criteria, they will be packaged for emplacement in the underground

d. A radiological survey will be performed on the EFB and associated equipment

e. Decontamination will be performed on all EFB equipment that is contaminated

f. HEPA filters will be installed

9. The EFB ventilation systems will be tested to meet surveillance requirements

n. Underground operations will recommence

Performance of these steps will decrease the potential for TRU or TRU mixed waste being generated during the decommissioning of the EFB. In the unlikely event that there is radiologically contaminated waste generated during the EFB decommissioning, it may be designated as low level radioactive waste and shipped to a licensed disposal facility.

\section{Sampling and Characterization}

Radioactivity - Methods for assuring that equipment is not contaminated and ready for free release are listed in Attachment 3 of this plan (Reference 78).

Equipment decontaminated will require a verification survey before release for disposition.

\section{SizeNolume Reduction}

There is currently no requirement for size/volume reduction. However, the WIPP has an active waste minimization and pollution prevention plan which applies both size and volume reduction where possible. This technology will be considered during decommissioning and utilized if technically and economically feasible, or necessary for emplacement of this waste into the last HWMU. 


\section{Removal and Packaging}

Removal of radioactive equipment will be performed under strict health physics control following the procedures specified in documents listed in Attachment 3 of this plan; and approved work instructions (Reference 74 ).

The waste will be packaged in approved containers as specified in Section 1.6 .8 of this plan.

\section{Emplacement}

Decontamination wastes will be emplaced in the last HWMU as derived mixed waste.

\subsubsection{Removal of Nonradioactive Equipment}

\section{Isolation of System and Cutting of Pipe}

System isolation and pipe cutting is marginally applicable to the WIPP facilities. Separate work instructions will be developed for the removal of closed systems using standard industry practices.

\section{Verification of Noncontaminated Condition}

All systems external to the Waste Handling and Storage areas will have been declared clean to the limits specified in Section 1.3.3 of this document during the site radiological characterization survey. Systems within those areas will require health physics surveys prior to removal. All systems that contained or may have contained hazardous materials will require sampling and possible flushing prior to removal.

\section{Removal and Packaging}

Removal of nonradioactive equipment will be performed following approved work instructions which will be developed by Work Control.

\section{Holding Area}

Location - The asphalt pad southeast of the waste handling building will be designated as the primary holding area for nonradioactive equipment.

Traffic Management - Equipment awaiting disposition will be segregated from access by non-authorized personnel. 


\section{Disposition}

Retired - Nonradioactive equipment that is not scrap or salvage will be placed on the excess property list.

Disposal - Nonradioactive equipment that cannot be retired will be dispositioned as scrap or salvage.

\subsubsection{Removal of Power and Control Systems}

Circuits will be de-energized and removed as equipment and facilities are made available for disconnect. The diesel generators will be maintained until all vital loads are removed. After all site loads are removed, the utility will be notified to remove their site feed.

Removal of the uninterruptable power supplies (UPS) will present no additional problems. All batteries will be removed and excessed.

\section{Operations Interface}

Close coordination between the operations and construction managers will be required to assure that necessary circuits for the remaining facility are maintained as the circuits are removed.

\section{Switch-over to Construction Power}

Primary power will be utilized until all its electrical systems are completely removed. Construction power is not required during the decommissioning of the site.

\section{Disposition}

Where economically feasible based upon the criteria of cost, condition, etc. electrical equipment will be retired or declared excess as appropriate.

\subsubsection{Removal of Contaminated Surfaces}

\section{Potentially Contaminated Areas}

Walls, Floors, and Structures - Surfaces that will be potentially contaminated are in the Waste Handling Building CH Bay, Overpack and Repair Room, RH Bay, Cask Unloading Room, Hot Cell, Cask Transfer Shuttle car, Shaft Access, Waste Handling Building Ventilation system, and Exhaust Filter Building.

Shafts and Drifts - The Waste Handling Shaft, Exhaust Shaft, exhaust drift, and the underground drift from the Waste Station to the waste panel are areas of potential contamination. The Exhaust Shaft and the E-300 drift from S-1600 to S -400 have the 'potential for contamination if an emplaced container is breached. 
The waste packages are surveyed prior to downloading, and therefore the potential for waste shaft contamination is limited to waste conveyance accident scenarios, which are deemed incredible events. The Waste Shaft will be a part of the site radiological characterization survey, but it is not anticipated that any decontamination will be required in the shaft. All shafts and drifts will be surveyed for the site radiological survey, but it is anticipated that the need for decontamination, if any, will be confined to the access drifts from the waste station to the entrance to the final panel.

\section{Removal Controls}

Decontamination will commence at the areas farthest from the waste shaft and proceed to the shaft access, and recommence from the shaft waste station south to the last panel. The minimum volume of material should be removed to control the storage volume needed in the underground.

\section{Removal Methods}

Applicable methods of contamination removal are listed in Section 1.6.4.

\subsubsection{Closure of Last Hazardous Waste Management Unit}

\section{Closure Survey}

A radiological closure survey will be performed in accordance with approved procedures. RCRA closure will be performed in accordance with the specifics defined in Chapter I of the RCRA Part B Permit Application.

\subsubsection{Closure of Mine Underoround}

\section{Equipment Removal}

Equipment and materials will be removed from the mine to the extent practicable.

Electrical Systems - Electrical systems will be removed as the closure progresses out of the mine.

Mining Equipment - As the mining equipment is no longer needed it will be removed through the waste handling shaft. Some pieces of the equipment may require disassembly or cutting to fit into the shaft.

Support Equipment - Support equipment such as golf carts, ambulance, fire truck, portable offices, etc. will be removed from the mine and dispositioned as they become excess. 


\subsubsection{Shaft Sealing and Plugaing}

Shafts will be plugged in accordance with acceptable sealing techniques.

Shaft Seals - An essential task during the decommissioning of the waste repository will be sealing the remaining holes and shafts. Shaft seal design alternatives have been studied for several years. A reference design is available.

\subsubsection{Demolition and Removal of Structures}

\section{Criteria}

All site structures with the possible exception of the Hot Cell portion of the Waste Handling Building are to be removed during the decommissioning. The Hot Cell in the RH portion of the Waste Handling Building may remain as part of the permanent marker system. Criteria for free release of structures is delineated in Section 1.3.3 of this document.

\section{Removal of Contamination}

Appropriate techniques will be applied for the conditions of the contamination including quantity of contaminant, location, worker health and safety, fixed or loose, surface to be decontaminated, etc.

\section{Removal Techniques}

Applicable methods of contamination removal are listed in Section 1.6.4.

\section{Verification of Noncontaminated Status}

Structures that were shown noncontaminated by the site radiological and hazardous constituent characterization and historical records may be removed when there is no further use for them. Structures that indicated radiological contamination, will require a verification survey after decontamination. Those structures that are then shown clean will be removed as the schedule permits.

\section{Disposition}

Transferred - Structures will be declared excess in accordance with applicable Federal and DOE Property Management Regulations.

\subsubsection{Einal Radiological Survey and Hazardous Constituent Analyses}

The final radiological survey and hazardous constituent analyses will encompass the entire WIPP site. 


\section{Sampling and Statistical Analysis}

Approved procedures will be utilized to perform the final radiation survey and swipe or material sampling.

\section{Environmental Monitoring}

A final environmental monitoring survey will be performed to assure that the facility has not created any environmental hazards. Environmental monitoring will continue after decommissioning concurrent with long-term monitoring.

\section{Survey Plan}

Surveys will be performed in accordance with approved procedures.

\section{Confirm Structures Meet Disposition Objectives}

All structures with the possible exception of the Hot Cell portion of the Waste Handling Building will have been removed. The final radiological survey of the Hot Cell will verify meeting disposition objectives.

\subsubsection{Restoration of Site}

\section{Decommissioning of Solid Waste Management Units}

There are 13 discernable groups of SWMU at the WIPP site. The following table lists those groups and their descriptions. All SWMUs will be characterized and closed in accordance with applicable federal and state regulations. Recontoured sites will be reclaimed in accordance with the WIPP Land Management Plan.

\begin{tabular}{|c|c|c|c|}
\hline $\begin{array}{c}\text { SWMU } \\
\text { No. }\end{array}$ & Unit Type & Unit Description & Waste Description \\
\hline $\begin{array}{l}001 \\
a-a b\end{array}$ & Mud Pits & $\begin{array}{l}\text { Approximately } 46 \\
\text { decommissioned mud pits } \\
\text { are located on } 28 \text { drill } \\
\text { pads, which were used for } \\
\text { settling drill cuttings out of } \\
\text { the drilling fluids being } \\
\text { used in drilling holes to } \\
\text { support hydrologic testing } \\
\text { and monitoring, potash } \\
\text { evaluation, and drilling for } \\
\text { hydrocarbons. }\end{array}$ & $\begin{array}{l}\text { Sodium- and potassium } \\
\text { chloride saturated brine; } \\
\text { starch; bentonite gel; diesel } \\
\text { fuel; drill cuttings; metal } \\
\text { cuttings; grease; hydraulic } \\
\text { fluid; motor oil. }\end{array}$ \\
\hline
\end{tabular}




\begin{tabular}{|c|c|c|c|}
\hline $\begin{array}{l}002 \\
a-d\end{array}$ & $\begin{array}{l}\text { Salt and Top } \\
\text { Soil Storage } \\
\text { Areas }\end{array}$ & $\begin{array}{l}\text { A total of four areas } \\
\text { ranging in size from } 3 \text { to } 15 \\
\text { acres used for salt and } \\
\text { topsoil storage. }\end{array}$ & $\begin{array}{l}\text { Salt; topsoil; traces of } \\
\text { hydraulic oil; motor oil; } \\
\text { diesel fuel; and scrap steel. }\end{array}$ \\
\hline $\begin{array}{l}003 \\
a-b\end{array}$ & Landfills & $\begin{array}{l}\text { Two landfills used for } \\
\text { disposal of construction } \\
\text { debris. }\end{array}$ & $\begin{array}{l}\text { Foundation excavation soils; } \\
\text { concrete; scrap wood; and } \\
\text { metal. }\end{array}$ \\
\hline $\begin{array}{l}004 \\
a-c\end{array}$ & Storage Yards & $\begin{array}{l}\text { Three yards used for } \\
\text { storage of construction and } \\
\text { maintenance materials, } \\
\text { wastewater, and used oils } \\
\text { or materials that can be } \\
\text { reclaimed or recycled. }\end{array}$ & $\begin{array}{l}\text { Water contaminated with } \\
\text { motor oil, hydraulic oil, and } \\
\text { diesel fuel; used hydraulic } \\
\text { oil, motor oil, antifreeze, } \\
\text { glycol-based oils, chemical } \\
\text { grout; used lead acid } \\
\text { batteries; scrap metal. Used } \\
\text { hydrocarbons are collected } \\
\text { in containers. }\end{array}$ \\
\hline $\begin{array}{l}005 \\
a-c\end{array}$ & $\begin{array}{l}\text { Concrete } \\
\text { Batch Plants }\end{array}$ & $\begin{array}{l}\text { Three areas used as } \\
\text { temporary locations for } \\
\text { concrete batch plants. }\end{array}$ & $\begin{array}{l}\text { Concrete; trace amounts of } \\
\text { motor oil and grease. }\end{array}$ \\
\hline $\begin{array}{l}006^{*} \\
a-b\end{array}$ & Holding Ponds & $\begin{array}{l}\text { Two ponds used to hold } \\
\text { brine drilling fluid from the } \\
\text { drilling of the salt handling } \\
\text { and waste handling shafts. }\end{array}$ & $\begin{array}{l}\text { Saturated brine; bentonite; } \\
\text { drill cuttings; hydraulic oil } \\
\text { and grease. }\end{array}$ \\
\hline $\begin{array}{l}007 \\
a-c\end{array}$ & $\begin{array}{l}\text { Evaporation } \\
\text { Ponds }\end{array}$ & $\begin{array}{l}\text { Three ponds used for the } \\
\text { evaporation of water. }\end{array}$ & $\begin{array}{l}\text { Water; soap; nonhazardous } \\
\text { cleaning solutions; oil; } \\
\text { unsaturated salt brine. }\end{array}$ \\
\hline $\begin{array}{l}008 \\
a-r\end{array}$ & $\begin{array}{l}\text { Surface } \\
\text { Satellite } \\
\text { Accumulation } \\
\text { Areas }\end{array}$ & $\begin{array}{l}\text { Ten hazardous waste or } \\
\text { used petroleum product } \\
\text { satellite accumulation } \\
\text { areas; two hazardous } \\
\text { waste staging areas. }\end{array}$ & $\begin{array}{l}\text { Nonradioactive, site- } \\
\text { generated wastes, collected } \\
\text { in containers including spent } \\
\text { solvents, aerosol cans, oily } \\
\text { rags, expired chemicals, and } \\
\text { paint products. }\end{array}$ \\
\hline $\begin{array}{l}009 \\
a-1\end{array}$ & $\begin{array}{l}\text { Underground } \\
\text { Satellite } \\
\text { Accumulation } \\
\text { Areas }\end{array}$ & $\begin{array}{l}\text { Ten hazardous waste or } \\
\text { used petroleum product } \\
\text { satellite accumulation } \\
\text { areas. }\end{array}$ & $\begin{array}{l}\text { Nonradioactive, site- } \\
\text { generated wastes, including } \\
\text { spent solvents, aerosol } \\
\text { cans, oily rags, used oils, } \\
\text { spent lead acid batteries, } \\
\text { grout, and cement. } \\
\text { Hazardous waste and used } \\
\text { petroleum products are } \\
\text { collected in containers. }\end{array}$ \\
\hline
\end{tabular}




\begin{tabular}{|c|c|c|c|}
\hline $\begin{array}{l}010 \\
a-d\end{array}$ & Shaft Sumps"* & $\begin{array}{l}\text { An area at the bottom of } \\
\text { each of the four WIPP } \\
\text { shafts that collected } \\
\text { construction debris or } \\
\text { accumulated brine. }\end{array}$ & $\begin{array}{l}\text { Welding residue; scrap } \\
\text { wood and metal; salt; Class } \\
\mathrm{C} \text { cement; chem-seal; } \\
\text { bentonite; grease and oil; } \\
\text { cement and chem grout; } \\
\text { Rustler formation brine; } \\
\text { washwater. }\end{array}$ \\
\hline $\begin{array}{l}011 \\
a-e\end{array}$ & $\begin{array}{l}\text { Sewage } \\
\text { Treatment } \\
\text { Facility }\end{array}$ & $\begin{array}{l}\text { Five ponds used for WIPP } \\
\text { sewage treatment. }\end{array}$ & $\begin{array}{l}\text { Sanitary waste; neutralized } \\
\text { film developer, and oil. }\end{array}$ \\
\hline 012 & $\begin{array}{l}\text { Nonhazardous } \\
\text { Solid Waste } \\
\text { Collections } \\
\text { Bins }\end{array}$ & $\begin{array}{l}\text { Twenty portable bins used } \\
\text { for solid waste collection. }\end{array}$ & $\begin{array}{l}\text { Nonhazardous solid waste } \\
\text { including nonliquid sanitary } \\
\text { waste and industrial waste. }\end{array}$ \\
\hline 013 & $\begin{array}{l}\text { TRU Mixed } \\
\text { Waste } \\
\text { Management } \\
\text { Units }\end{array}$ & $\begin{array}{l}\text { Areas where transuranic } \\
\text { (TRU) mixed waste was } \\
\text { managed during the } \\
\text { Disposal Phase. Includes } \\
\text { contact and remote } \\
\text { handled TRU areas of the } \\
\text { Waste Handling Building } \\
\text { and Panels } 1 \text { through } 8 \text { in } \\
\text { the underground. Waste } \\
\text { will be in approved } \\
\text { containers. }\end{array}$ & $\begin{array}{l}\text { Radioactive mixed waste } \\
\text { consisting of TRU waste that } \\
\text { is co-contaminated by } \\
\text { various listed solvents, or } \\
\text { which contain characteristic } \\
\text { waste consisting mostly of } \\
\text { metals. }\end{array}$ \\
\hline
\end{tabular}

"Both holding ponds designated as $006 a$ and $006 \mathrm{~b}$ have been remediated.

* The AIS \& ES terminate at the storage horizon, but are designated as sumps for the RCRA Part B Permit application.

\section{Removal of Site Boundary Structures}

Fences - Fences around the surface facilities will be removed and either retired or transferred. A fence line shall be established to control access to the repository footprint area (the waste disposal area projected to the land surface.) for the active controls after closure. A standard five-strand barbed wire cattle guard fence shall be erected along the perimeter of the repository surface footprint. The fence shall have gates placed approximately mid-way along each of the four sides.

Guardhouse - Structures will be declared excess in accordance with applicable federal and DOE property management regulations. 


\section{Grading}

Following removal of all structures and surfaces, as well as buried piping, conduit, and wiring, the surface will be graded to near the original contour.

\section{Revegetation}

Following closure of the WIPP site, the area will be replanted in accordance with applicable regulations and agreements.

\section{Facility and Site Closeout}

A final inspection of the facility will be conducted to ensure that the area has been retumed to as close as reasonably possible to the surrounding landscape. Monitoring for assurance that the vegetation and animal populations are returning to normal will be accomplished within the Post-Closure Monitoring Program.

\subsubsection{Eacility Release and Reporting}

\section{Certification of Unrestricted Level for Release}

Certification of unrestricted level for release will involve the evidence of historical reports of surveys and the results of the site radiological characterization survey conducted at the start of the decontamination and decommissioning effort, and the final radiological survey and hazardous constituent analysis.

\section{Release of Site and Structures}

Individual structures will be released as excess property as they are found free of contamination, as specified in Section 1.6.4 of this plan, and there is no further use for them at the site.

\section{Final Program Report}

A final program report will be issued for the decontamination and decommissioning program to summarize the decommissioning process and the steps taken to obtain closure status.

\subsection{Facility Modification}

\subsubsection{Material Staging/Storage Facility}

Laydown, staging, and storage areas will be designated for use during the decommissioning process. These areas will require the same level of survey and cleanup as the other portions of the site for free release and closeout. 
- It is anticipated that a staging area will be required for oils and ethylene glycol waste. There is an anticipated 1500 gallons of waste ethylene glycol with $\mathbf{3 0 0 0}$ galions of flush water waste. Drum storage or a roll-off tank (preferred method), will be required for the ethylene glycol waste. All ethylene glycol will be surveyed and sampled. Once a determination is made that the material is not radiologically contaminated, all ethylene glycol will be sent off-site to be recycled.

\subsubsection{Liquid Treatment Facility}

There is currently no requirement for a liquid treatment facility at the WIPP. However, all liquid site derived wastes will be solidified per current WIPP procedures and disposed of in the repository.

\subsection{Waste Management}

\subsubsection{Radioactive Materials}

\section{Types}

All radioactive waste generated will be designated as "derived" waste. The waste will not contain any constituents that would prevent it from meeting the DD-WAC, and will be emplaced in the last HWMU.

\section{Quantities}

The quantities of radioactive mixed waste that will be emplaced into the last HWMU at decommissioning of the WIPP facility is expected to be low due to the "start-clean, stay-clean" operating philosophy. All contamination events during the life of the facility will be controlled and cleaned immediately.

\section{Dose Rates}

To meet the criteria for contact handled waste, the dose rates must not exceed 200 millirem per hour (mrem/hr).

\subsubsection{Hazardous Wastes}

\section{Types}

The WIPP facility controls the types and amounts of hazardous materiais that are brought onto the site. Polychiorinated biphenyls and asbestos are excluded from use on the site. This process reduces the potential for hazardous wastes to be generated during D\&D. 


\section{Quantities}

The quantities of hazardous waste that will be generated during decommissioning of the WIPP facility is expected to be low due to the "start-clean, stay-clean" operating philosophy. All contamination events during the life of the facility will be controlled and cleaned before further work may continue in the area.

\section{Disposition}

Hazardous materials will be characterized and dispositioned utilizing the current WIPP procedures listed in Attachment 3 of this plan (References 33, 46, 51, 52, 55).

Packaging - Packaging will meet all applicable requirements.

On Site Storage - Nonradioactive hazardous materials will be stored in satellite waste accumulation areas, and transferred to the staging area in accordance with procedures listed in Attachment 3 of this plan.

Transportation - Nonradioactive hazardous materials will be shipped in accordance with procedures listed in Attachment 3 of this pian.

Disposal - Nonradioactive hazardous materials disposal will be at a permitted treatment, storage, or disposal facility.

\subsection{Licensing and Requlatory lseves}

\subsubsection{Requiator Compliance}

Because of the stringent requirements for managing radioactive materials, the closure of the WIPP facility will require longer than the 180 days allowed in the regulations. Therefore, an extension to the 180 days must be requested for the closure in the permit application. If, for some unforeseen reason, closure cannot be completed within the time(s) specified, the DOE will request an extension to the closure time. This request will be submitted to the NMED in writing, at least 30 days before the expiration of the time allowed in the closure plan, and will describe the reason the extension is needed and estimate the amount of additional time needed to complete the closure. During the extended closure period, the DOE will continue to demonstrate compliance with applicable permit requirements and that all steps will be taken to prevent threats to human health and the environment as a result of TRU mixed waste management at the WIPP facility.

No later than the submission of the certification of closure of each hazardous waste disposal unit, the owner or operator must submit to the local zoning authority, or the authority with jurisdiction over local land use, and to the Regional Administrator, a survey plat indicating the location and dimensions of hazardous waste disposal units with respect to permanently surveyed benchmarks. This plat must be prepared and certified by a professional land surveyor. The plat filed with the local zoning authority, 
or the authority with jurisdiction over local land use, must contain a note, prominently displayed, which states the owner's or operator's obligation to restrict disturbance of the hazardous waste disposal unit in accordance with the applicable regulations.

The Final Safety Analysis Report will require modification to meet the requirements of the Consultation and Cooperation agreement between the State of New Mexico and the U. S. Department of Energy.

A WIPP specific closure and post closure NEPA document will be developed prior to initiating the final closure phase.

\subsubsection{Permit Modifications}

\section{Current Facility Status}

The facility is currently awaiting authorization to receive TRU mixed waste for disposal.

Permit modifications may be necessary for decommissioning. Direction on this subject can be found in 40 CFR 270.41, 270.42, and 270.43 .

40 CFR \$270.41 Modification or Revocation and Reissuance of Permits, \$270.42 Permit Modification at the request of the Permittee, and \$270.43 Termination of Permits, are detailed in the Code of Federal Regulations.

Revisions to the FSAR will be required to incorporate the D\&D changes in work scope, direction, organization, etc.

Development of an appropriate NEPA document, possibly a supplemental environmental impact statement will be necessary to address environmental changes resulting from substantial changes in the WIPP mission.

\section{Prevention of Criticality}

Adherence to the waste acceptance criteria for waste received at the site and for derived waste will assure that criticality is not an issue during the decontamination and decommissioning phase.

\section{Release Prevention}

Maintenance of the negative pressure in the waste handling areas and adherence to the applicable procedures will prevent the release of contaminants.

\section{Decommissioning Activities Safety Analysis}

DOE Order 5480.21, Unreviewed Safety Questions, Section 10, Program Requirements, requires that a contractor authorized to operate DOE nuclear facilities shall perform safety evaluations for all changes in facility and procedures as described 
in the existing safety analyses and tests or experiments not described in the existing safety analyses.

Decommissioning is described in the Final Safety Analysis Report (FSAR), and this plan does not change the facility or procedures beyond that described in the FSAR.

The need for a decommissioning activities safety analysis will be evaluated prior to initiation of the decontamination and decommissioning plan. If a safety analysis is required for decommissioning activities, it will be documented through the FSAR update.

\section{Changes to Operational Safety Requirements (OSR)}

Decommissioning of WIPP is not expected to require a change in operational safety requirements. The requirements will need to be individually inactivated (as an unresolved safety question) as each of those systems covered by the OSRs are removed from service.

\subsubsection{Residual Radioactivity}

\section{Post-Decommissioning Radiation Survey Program}

Following decontamination (which will ensure the removal of waste residues at background levels) and decommissioning of the WIPP site, there will be no need for a radiation survey program. This may change in the final version of the Post-Closure Monitoring Plan.

\section{Certification Requirements}

Certification of post-decommissioning radiation levels will be provided in the postclosure notification to the State of New Mexico.

\subsection{Records Disposition}

Quality records generated during the decommissioning process will be identified on the decontamination and decommissioning section records inventory and disposition schedule. Following review of the records by cognizant personnel the records will be transmitted to Project Record Services.

A copy of records of waste disposal locations and quantities specified under 40 CFR $\$ 264.73(b)(2)$ will be submitted to the regional administrator and local land authority within 60 days of closure of the facility. 


\subsection{Supporting Documents}

These documents are required to support the overall decommissioning program. This section provides a brief overview of the documents and document control numbers. Several of these documents will also address the requirements of the long-term protection plan for acceptable cleanup levels, sampling and analysis plans, and QAVC specifications.

The documents listed below that are designated as "currently in place" are reviewed and updated periodically to ensure correctness with the current facility configuration and operational status.

\subsection{Detailed Implementation Plan.}

A detailed implementation plan is not credible at this time for the completion of the decommissioning of the Waste Isolation Pilot Plant. Processes that are in current use and will be utilized for decontamination and decommissioning are detailed in procedures that are currently in place. New systems that are procured for the decontamination and/or decommissioning will require separate process specific procedures for operation. Prior to final waste emplacement a detailed implementation plan will be developed.

\subsection{Enoineering Plan}

Procedures are currently in place which will direct engineering activities during the decommissioning process and are listed in Attachment 3 of this plan (References 5870).

\subsection{Cost. Schedule, and Financing Plan}

Procedures are currently in place for financial aspects of decommissioning and are listed in Attachment 3 of this plan (References 86, 87).

At this date cost and schedule estimates are of little true value in predicting the actual numbers and timelines for 28 years in the future. A conceptual cost estimate is available from the Waste Isolation Division Long-Term Regulatory Compliance Group. A cost, schedule, and budget will be developed prior to final waste emplacement.

\subsection{Solid Waste Management Unit Closure Plan}

A plan will be developed for closure of the solid waste management units. The plan will be developed to accomplish the closures of the separate SWMUs in accordance with applicable regulations. 


\subsection{Health and Safety Plan}

Procedures are currently in place to ensure the health and safety of workers and the public. These procedures are listed in Attachment 3 of this plan (Reference 72).

\subsection{Quality Assurance Plan}

Procedures are currently in place in to meet the requirements of DOE Order $5700.6 \mathrm{C}$. These procedures are listed in Attachment 3 of this plan (Reference 82).

10 CFR 830.120 is implemented through DOE Order $5700.6 \mathrm{C}$.

\subsection{Emeroency Plan}

Emergency procedures are currently in place. These procedures are listed in Attachment 3 of this plan (Reference 76).

\subsection{Environmental Report/NEPA Documentation}

Procedures are currently in place for environmental reporting and NEPA documentation and are listed in Attachment 3 of this plan (References 47, 48, 50).

\subsection{Radiological Protection Plan}

Policies are currently in place for assuring that worker exposures to radiological and chemical hazards are kept low. These policies are listed in Attachment 3 of this plan (References 72, 73, 81).

\subsection{Physical Security Pian}

Procedures are currently in place for physical security. These Procedures are listed in Attachment 3 of this plan (Reference 71).

\subsection{Environmental Monitoring Plan}

Procedures are currently in place for environmental monitoring and are listed in Attachment 3 of this plan (References $44,45,52,53$ ).

\subsection{Supplemental Environmental Impact Statement}

Development of a Supplemental Environmental Impact Statement will be necessary to address environmental issues resulting from substantial changes in the WIPP mission. 


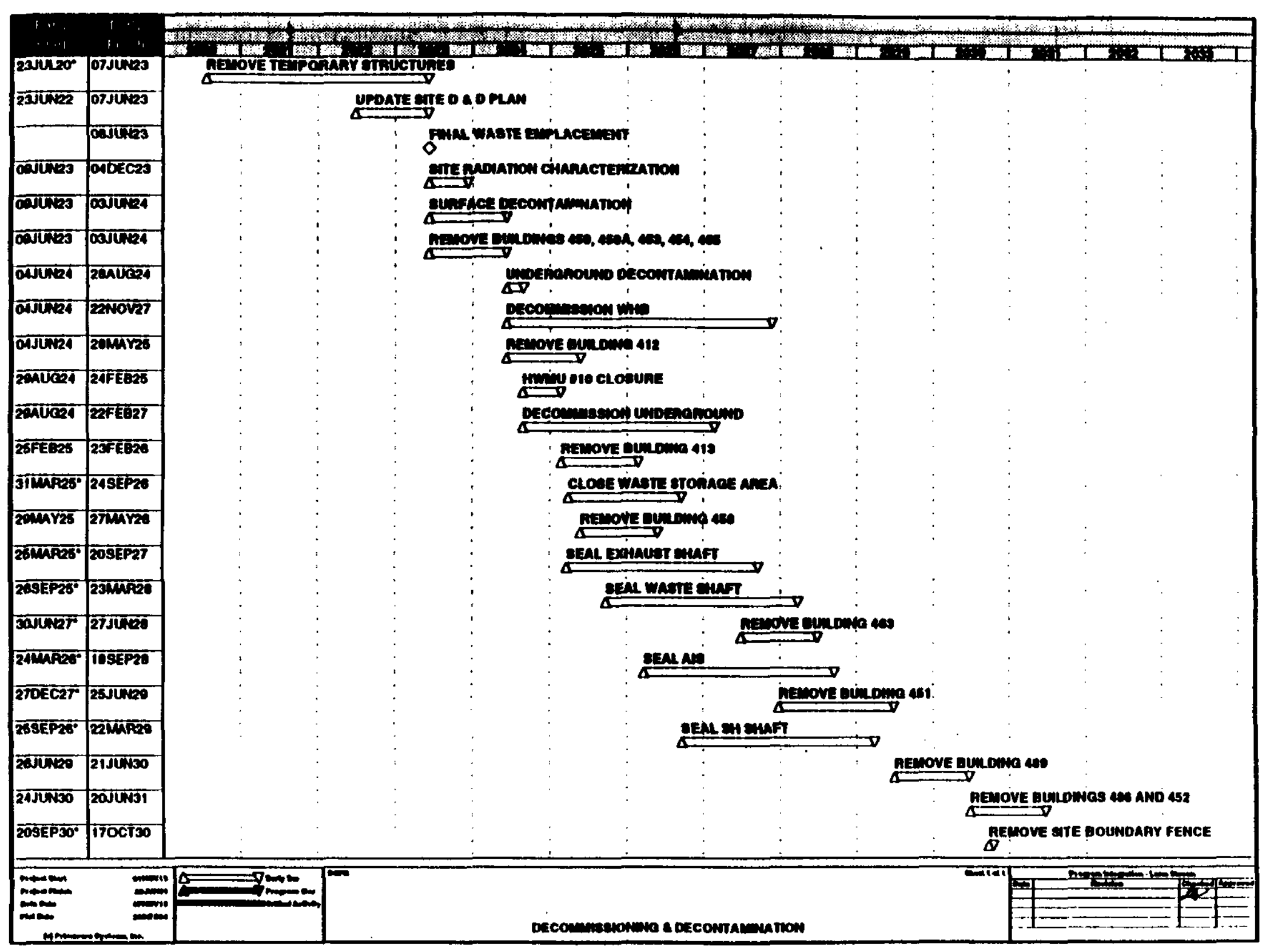




\section{Decontamination and Decommissioning Management}
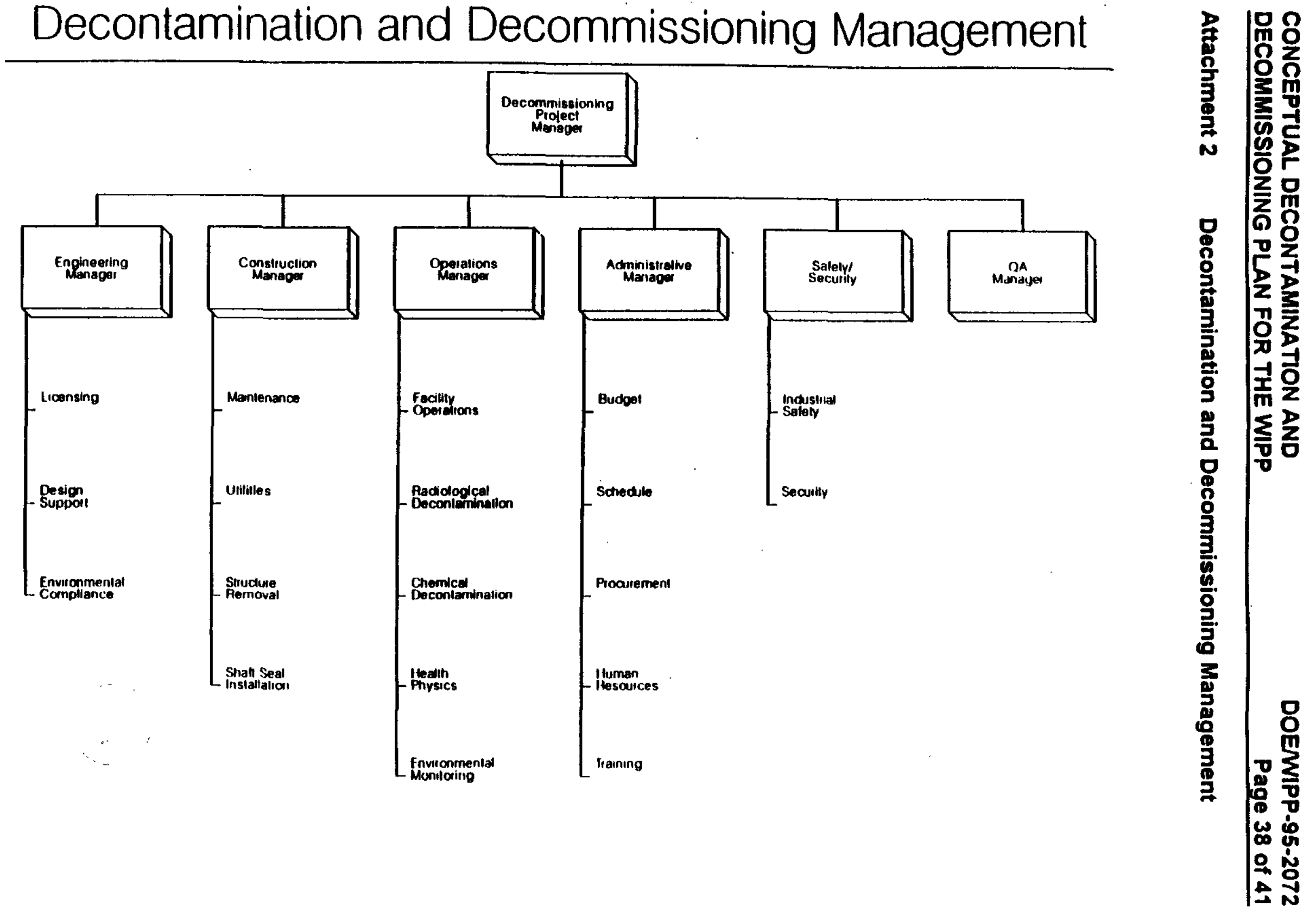


\section{Attachment 3 References}

1. $\quad 10$ CFR 830.120, Quality Assurance requirements

2. 24-C-022-W, WIPP Site Facility Master Plan

3. 29 CFR 1910.1200, Hazard Communication

4. 40 CFR 191, Environmental Radiation Protection Standards for Management and Disposal of Spent Nuclear Fuel, High-Level and Transuranic Radioactive Wastes

5. 40 CFR 194, Criteria for the Certification and Determination of the Waste Isolation Pilot Plant's Compliance with Environmental Standards for the Management and Disposal of spent Nuclear Fuel, High-Level and Transuranic Radioactive Wastes

6. 40 CFR 261, Identification and Listing of Hazardous Waste

7. 40 CFR 264, Standards for Owners and Operators of Hazardous Waste Treatment, Storage, and Disposal Facilities

8. 40 CFR 268, Land Disposal Restrictions

9. 40 CFR 270, EPA Administered Permit Programs: The Hazardous Waste Permit Program

10. 40 CFR 280, Underground Storage Tanks

11. 41 CFR 101, Federal Property Management Regulations

12. 41 CFR 109, Department of Energy Property Management Regulations

13. 49 CFR 100 THROUGH 199, Research and Special Programs Administration, Department of Transportation

14. ANSUANS-15.10-1981, American National Standard for Decommissioning of Research Reactors

15. ASTM E1167 87, Standard guide for Radiation Protection Program for Decommissioning Operations

16. ASTM E1278 88, Standard Guide for Radioactive Pathway Methodology for Release of Sites Following Decommissioning

17. ASTM E1281-89, Standard Guide for Nuclear Facility Decommissioning Plans

18. CAO QAPD (Quality Assurance Program Description)

19. DOEJEIS-0026, Final Environmental impact Statement

20. DOE/ID-10500, Department of Energy Hoisting and Rigging Manual, April 1993, Assistant Secretary for Environment, Safety and Health, Washington, DC 20585

21. DOE Order 1540.1A, Materials Transportation and Traffic Management

22. DOE Order 5820.2A, Radioactive Waste Management

23. DOE Order 5820.2B, Draft (4/29/93) - Decontamination and Decommissioning of Radioactively Contaminated Facilities

24. DOE Order 5700.6C, Quality Assurance Program Implementation Guide

25. DOEJCAO-94-2003, WIPP Regulatory Compliance Strategy and Management Plan for Demonstrating Compliance to Long-Term Disposal Standards

26. DOEMIPP 87-016, Draft Rev. 1, A Plan for the Implementation of Assurance Requirements in Compliance with 40 CFR 191.14 at the Waste Isolation Pilot Plant

27. DOEMIPP 91-005, Waste Isolation Pilot Plant RCRA Part B Permit Application 28. DOEMIPP 93-029, Waste Isolation Pilot Plant Repository Monitoring Program Strategic Plan 
29. DOEMIPP 94-024, Waste Isolation Pilot Plant 1994 Environmental Monitoring Plan

30. ElB/SWMR-4, New Mexico Solid Waste Management Regulations

31. General Plant Design Description (GPDD) Revision 0

32. HA:94:6528, Revision 2 to WIPP Active Controls after Closure Design Criteria, R. J. Rodriguez, 9/14/94

33. 20 Now Mexico Administrative Code 4.1 Subpart V

34. IAEA Safety Series No. 105, The Regulatory Process for the Decommissioning of Nuclear Facilities

35. Minerals Act of 1947, (Act of July 31, 1947, 30 U.S.C. 602, 603.)

36. NUREG-0586, Final Generic Environmental Impact Statement on Decommissioning of Nuclear Facilities

37. Permanent Marker Conceptual Design Report, Draft, Revision 2, November 1994

38. PL 96-164, Department of Energy National Security and Military Applications of Nuclear Energy Authorization Act of 1980

39. PL 102-579, Waste Isolation Pilot Plant Land Withdrawal Act

40. Waste Isolation Pilot Plant Project Technical Baseline for Regulatory Compliance.

41. Radiological Environmental Surveillance Air Sampling and Analysis at the WIPP Site, Carter, M. W., May 26, 1994, Westinghouse, Waste isolation Division, Carlsbad, NM

42. WIPP-DOE-069, Waste Acceptance Criteria for the Waste Isolation Pilot Plant

43. Working Agreement for Consultation and Cooperation, Rev. 1, Section N (DOE, 1981)

44. WP 02-14 WIPP National Pollutant Discharge Elimination System Storm Water Pollution Prevention Plan

45. WP 02-2, Environmental Compliance Assessment Program (ECAP) Plan

46. WP 02-601, Nonradioactive Hazardous Waste Management

47. WP 02-801, National Environmental Policy Act Compliance

48. WP 02-802, NEPA Evaluation, Tracking, and Monitoring

49. WP 02-9, WIPP Final Safety Analysis Report

50. WP 02-EC, National Environmental Policy Act Compliance Plan for the Waste Isolation Pilot Plant

51. WP02-EM1, WIPP Quality Assurance Project Plan for WIPP Site Effluent and Hazardous Materials Sampling

52. WPO2-EM2, The WIPP Site Effluent and Hazardous Materials Sampling Plan

53. WP02-EM1001, Sewage System Discharge Monitoring and Compliance

54. WP 02-RC1, Draft Waste Isolation Pilot Plant Project Technical Baseline for Regulatory Compliance

55. WP 06-101, Shipping of Nonradioactive Hazardous Materials

56. WP 06-108, Construction Landfill Operation

57. WP 06-HM3108, Request for Disposal

58. WP 09, Engineering Conduct of Operations and Procedures Manual

59. WP 09-CN3022, Engineering Document Control and Distribution

60. WP 09-007, Engineering and Design Document Preparation and Change Control 
61. WP 09-024, Configuration Management Board/Engineering Change Proposal (ECP)

62. WP 09-025, Engineering Data Transmittal/Design Input

63. WP 09-029, Cognizant Engineer Responsibilities

64. WP 09-031, Engineering Calculations

65. WP 09-033, Construction Labor Services

66. WP 09-034, Configuration Management Determination

67. WP 09-035, Site Development Planning and Project Authorization Process

68. WP 09-8, Specification Preparation Style Guide

69. WP 09-9, Configuration Management Plan

70. WP 09-CN3003, As Built Drawings: Process and Control

$\because 71$. WP 11-7, WIPP Security Manual

72. WP 12-1, WIPP Safety Manual

73. WP 12-2, WIPP ALARA Manual

74. WP 12-5, WIPP Radiological Control Manual

75. WP 12-6, VOC Monitoring Plan

76. WP 12-9, WIPP Emergency Plan and Administrative Procedures Manual

77. WP 12-10, Emergency Services Program Plan

78. WP 12-HP, WIPP Operational Health Physics Procedures Manual

79. WP 12-HP1100, Monitoring and Surveys

80. WP 12-HP3200, Radioactive Material Control

81. WP 12-RE3000, Radiological Control Program

82. WP 13-1, WID Quality Assurance Program Description

83. WP 14-TR3402, WIPP Training Policies

84. WP 14-TR3501, General Employee Training

85. WP 14-TR3502, Training Requirements for Subcontractor Personnel

:86. WP 15-6, Purchasing Policies and Procedures Manual

87. WP 15-605, Award and Administration of Construction Work 